\title{
Analisa Parameter Laser Marking pada Material Stainless Steel Terhadap Struktur Mikro dan Kedalaman Marking
}

\author{
Dikky Antonius ${ }^{1)^{\star}}$, Cyrilus Pandu ${ }^{1)}$ \\ ${ }^{1)}$ Program Studi Magister Teknik Mesin Universitas Kristen Indonesia \\ JIn. Maydjen Sutoyo no.2, 13630 \\ Email: dicky.antonius@uki.ac.id; cyrilluspandu95@gmail.com
}

doi: https://doi.org/10.24843/METTEK.2020.v06.i02.p07

\begin{abstract}
Abstrak
Proses marking merupakan proses pemberian identitas kepada material atau produk tertentu dalam rangka menghitung, memberi nomor produk, memberi tanda dsb. Bagi material yang keras dan diproduksi dalam jumlah yang banyak seperti logam, proses marking diberikan dengan Laser Marking Machine. Pada penelitian ini, mesin laser marking diatur pada kecepatan $50 \mathrm{~mm} / \mathrm{s}, 100 \mathrm{~mm} / \mathrm{s}$ dan $150 \mathrm{~mm} / \mathrm{s}$. Masing-masing kecepatan mesin menggunakan frekuensi dan power yang ditingkatkan: $20 \mathrm{~Hz}, 60 \mathrm{~Hz}$ dan $100 \mathrm{~Hz} ; 20 \%, 60 \%$ dan $100 \%$ power dari mesin, sementara penembakan dilakukan secara vertical dengan sudut $0^{\circ}$. Hasil menunjukkan bahwa frekuensi $60 \mathrm{~Hz}$ memperoleh kedalaman marking yang maksimal yaitu $3,58 \mu \mathrm{m}$ diantara parameter lainnya. Sementara dari penangkapan gambar mikrostruktur ditunjukkan bahwa kenaikan power dan frekuensi juga berpengaruh kepada melebarnya diameter dari hasil marking pada permukaan spesimen. Peningkatan kecepatan hanya berpengaruh terhadap kedalaman marking untuk frekuensi yang besar.
\end{abstract}

Kata kunci: Laser Marking Machine, Marking, Laser

\begin{abstract}
Marking process is one of manufacture process which function to give the identity for the material or final product. For material with high-hardness properties and high-volume production such as metal, the processed is held by Laser marking machine. In this research, the processes were held at speed $50 \mathrm{~mm} / \mathrm{s}, 100 \mathrm{~mm} / \mathrm{s}$ and $150 \mathrm{~mm} / \mathrm{s}$. The frequencies and powers are increased gradually for each speed of the laser machine. The frequencies and powers are $20 \mathrm{~Hz}, 60 \mathrm{~Hz}$ and $100 \mathrm{~Hz} ; 20 \%, 60 \%$ and $100 \%$ respectively, while the shoot-angle set at $0^{\circ}$ (vertically). The results show that the maximum depth $(3,58 \mu \mathrm{m})$ is achieve when the machines at speed $50 \mathrm{~mm} / \mathrm{s}$, while the frequencies and powers applied are $60 \mathrm{~Hz}$ and $100 \% \times 10$ Watt respectively. From the figure of microstructure, the increasing of power and frequencies will enhance the divergenceangle of laser thus increase the width of making process. The increasing of speed will increase the depth of marking for high frequencies such as $100 \mathrm{~Hz}$.
\end{abstract}

Keywords: Laser Marking, marking, Laser

\section{PENDAHULUAN}

Bagi industri manufaktur, pada masa modern ini setiap produsen dipaksa untuk mengikuti arus teknologi yang mengharuskan pekerjaan dibuat semakin cepat dan efisien dengan kualitas yang meningkat - atau setidaknya tetap. Baik dari proses hulu seperti pembentukan, permesinan, poles hingga ke proses akhir seperti pelapisan atau penandaan (marking). Proses marking adalah proses pemberian tanda, merk, kode atau bentuk tertentu pada produk jadi 
atau setengah jadi guna memberi identitas tertentu pada produk tersebut. Pada logam proses marking awalnya dilakukan dengan memahat secara manual menggunakan tangan dan alat pahat. Namun dengan meningkatnya angka produksi, dan semakin beragamnya material yang dipakai, maka proses marking tidak bisa dilakukan lagi secara manual dikarenakan ketidakefisienan dan prosesnya yang sangat lambat. Saat ini hal tersebut diatasi dengan mesin marking.

Ditinjau dari metodenya, mesin marking dapat dibedakan menjadi beberapa macam, antara lain metode ketuk (Dot-Peen), gores (Scribing), tekan (Stamp) dan juga laser (Light Amplification by Stimulated Emission of Radiation)[1]. Masing-masing metode mempunyai kelemahan dan keunggulannya tersendiri.

Laser marking sendiri memiliki prinsip kerja menggunakan kekuatan cahaya yang difokuskan pada sebuah area atau titik[2]. Umumnya cahaya yang digunakan pada ruang atmosfer bersifat menyebar atau diverge. Berbeda halnya dengan cahaya biasa, laser menggunakan cahaya yang dikeluarkan dengan panjang gelombang tertentu, yang cukup kuat untuk merusak logam dan bersifat converge. Umumnya laser marking dipakai pada materialmaterial yang mempunyai kekerasan tinggi dan membutuhkan keakuratan yang tinggi. Di samping itu, penggunaan laser digunakan juga bagi produk-produk yang sangat banyak, dengan demikian membutuhkan proses pemberian label yang efisien.

Bidang kerja pada mesin laser ini dapat dibagi menjadi tiga bagian utama: laser, kontroler, dan permukaan material. Kontroler (biasanya komputer) mengontrol arah, intensitas, kecepatan gerakan, dan penyebaran sinar laser yang diarahkan ke permukaan material[3]. Konfigurasi dan pengaturan parameter yang dihasilkan dari perangkat laser marking yang digunakan dapat mempengaruhi struktur permukaan baja stainless yang ditandai serta komposisi elemen dan fase.[4]

Dalam dunia medis teknik penandaan biasanya digunakan untuk pengenalan dan klasifikasi atau penelusuran implan yang memungkinkan analisis posterior dari perangkat medis implan logam setelah penggunaannya. Proses ini sangat mempengaruhi karakteristik permukaan yang terkena cairan tubuh manusia korosif, seperti struktur mikro, komposisi dan kekasaran permukaan.[5]

Beberapa penelitian telah menunjukkan beberapa pengaruh parameter laser terhadap proses permesinan seperti proses pemotongan [6], [7], dikarenakan laser banyak digunakan untuk proses pemotongan. Atau data-data tentang laser marking [3] [4] yang menunjukkan beberapa pengaruh kecil dari parameter mesin laser marking. Namun belum terdapat data yang jelas tentang pengaruh dari parameter secara keseluruhan dari mesin laser marking yang terhadap hasil marking sendiri. Pada penelitian ini diharapkan kekurangan ini dapat diselesaikan, dan dilengkapi dengan gambar mikrostruktur. Oleh karena itu penulis mengambil judul "ANALISA PARAMETER LASER MARKING PADA MATERIAL STAINLESS STEEL TERHADAP STRUKTUR MIKRO DAN KEDALAMAN MARKING".

\section{METODE}

\subsection{Prosedur Penelitian}

Pengumpulan data dilakukan dengan cara mengumpulkan fakta, objek kerja, situasi dan kondisi yang berada dilapangan yang dibutuhkan untuk menunjang tujuan penelitian. Datadata yang menunjang penelitian ini antara lain:

1. Laser Marking

Mesin laser marking yang digunakan dalam penelitian ini yaitu mesin marking dengan brand Technifor dengan type "Hybrid Series (H10)". Mesin ini memiliki power $\max 10$ Watt, frekuensi $10 \mathrm{kHz}-100 \mathrm{kHz}$ dan speed $\max 10.000 \mathrm{~mm} / \mathrm{s}$. Sehingga, memungkinkan untuk mengatur perubahan parameter di dalamnya. Mesin laser marking ini juga dapat memarking berbagai material antara lain steel, kayu, plastik dll. 
ojs.unud.ac.id/index.php/mettek

Dalam mesin marking ini memungkinkan untuk mengatur beberapa parameter di dalamnya antara lain kecepatan (speed), frekuensi (frecuency) dan daya (power). Proses marking material stainless steel dilakukan dengan ketinggian yang tetap (fix) $22,5 \mathrm{~cm}$ dari lensa ke benda kerja yang akan dimarking.

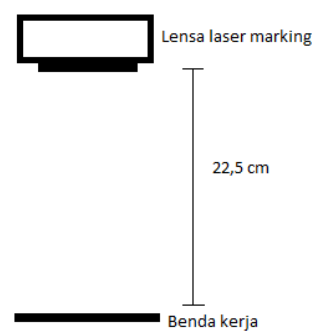

Gambar 1. Jarak Lensa ke Benda Kerja

2. Parameter

Parameter yang akan dianalisis antara lain kecepatan (speed), frekuensi (frecuency) dan daya (power). Penelitian ini menggunakan pola perubahan $3^{3}$ (satu sample terdapat 3 perubahan parameter yang sama). Sehingga menghasilkan 27 sample percobaan.

Perubahan parameter diatur dalam software khusus dari mesin laser tersebut. Pola perubahan parameter dapat dilihat dalam table dibawah:

Tabel 1. Tabel parameter

\begin{tabular}{cccc}
\hline Sample & Speed & Frequency & Power \\
\hline A1 & 50 & 20 & 20 \\
A2 & 50 & 20 & 60 \\
A3 & 50 & 20 & 100 \\
A4 & 50 & 60 & 20 \\
A5 & 50 & 60 & 60 \\
A6 & 50 & 60 & 100 \\
A7 & 50 & 100 & 20 \\
A8 & 50 & 100 & 60 \\
A9 & 50 & 100 & 100 \\
A10 & 100 & 20 & 20 \\
A11 & 100 & 20 & 60 \\
A12 & 100 & 20 & 100 \\
A13 & 100 & 60 & 20 \\
A14 & 100 & 60 & 60 \\
A15 & 100 & 60 & 100 \\
A16 & 100 & 100 & 20 \\
A17 & 100 & 100 & 60 \\
A18 & 100 & 100 & 100 \\
A19 & 150 & 20 & 20 \\
A20 & 150 & 20 & 60 \\
A21 & 150 & 20 & 100 \\
A22 & 150 & 60 & 20 \\
A23 & 150 & 60 & 60 \\
A24 & 150 & 60 & 100 \\
A25 & 150 & 100 & 20 \\
A26 & 150 & 100 & 60 \\
\hline & & & \\
\hline
\end{tabular}




\begin{tabular}{llll}
\hline $\mathrm{A} 27$ & 150 & 100 & 100 \\
\hline
\end{tabular}

3. Sample

Sample atau benda kerja di dalam penelitian ini menggunakan material strainless steel dengan ukuran $4 \times 5 \times 1 \mathrm{~cm}$. Jadi benda kerja atau sample akan dimarking sesuai format yang telah ditentukan. Format marking dapat dilihat pada gambar dibawah.

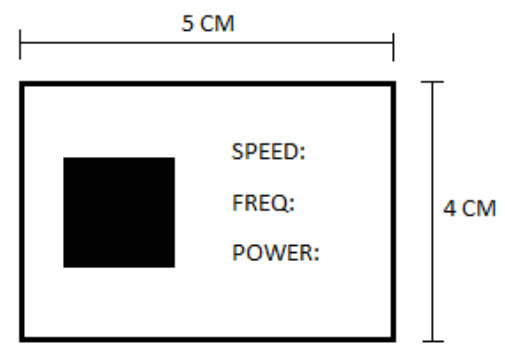

Gambar 2. Benda Kerja

4. Alat Ukur Kedalaman

Kedalaman permukaan marking pada penelitian ini akan menggunakan alat ukur dengan brand Mitutoyo type"SJ-411". Alat ukur ini memiliki akurasi pengukuran atau increments $0.1-25 \mathrm{~mm}$.

5. Alat Ukur Perubahan Struktur Mikro

Perubahan struktur mikro pada benda kerja (plat stainless steel) akan diukur menggunakan Microskop Optik dengan pembesaran 430x. Perubahan struktur mikro tersebut akan dilakukan dengan cara membandingkan permukaan benda kerja sebelum dan sesudah diberikan penandaan atau marking.

\section{HASIL DAN PEMBAHASAN}

\subsection{Gambar dan Tabel}

Hasil kedalaman (depth) proses marking untuk kecepatan $50 \mathrm{~mm} / \mathrm{s}, 100 \mathrm{~m} / \mathrm{s}$ dan $150 \mathrm{~mm} / \mathrm{s}$. dapat dilihat dari grafik pada gambar 3. Masing-masing gambar memperlihatkan kedalaman marking yang berbeda untuk frekuensi $20 \mathrm{~Hz}, 60 \mathrm{~Hz}$ dan $100 \mathrm{~Hz}$.

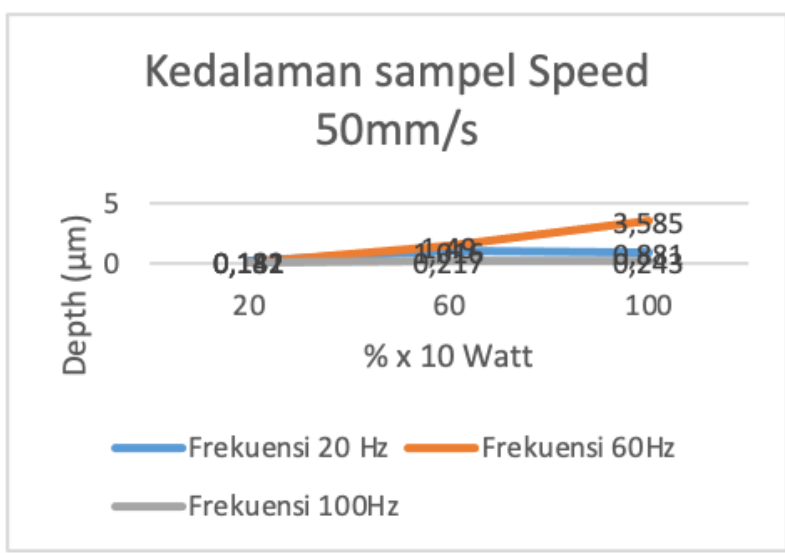

(a)

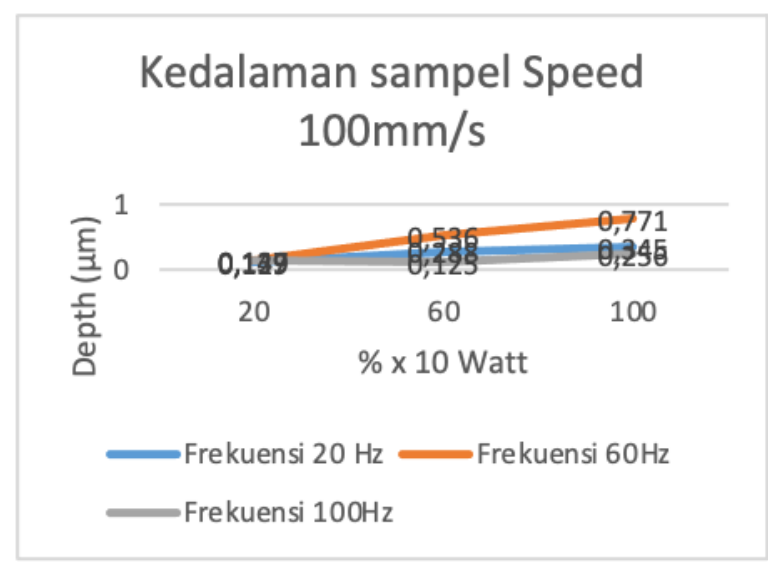

(b) 


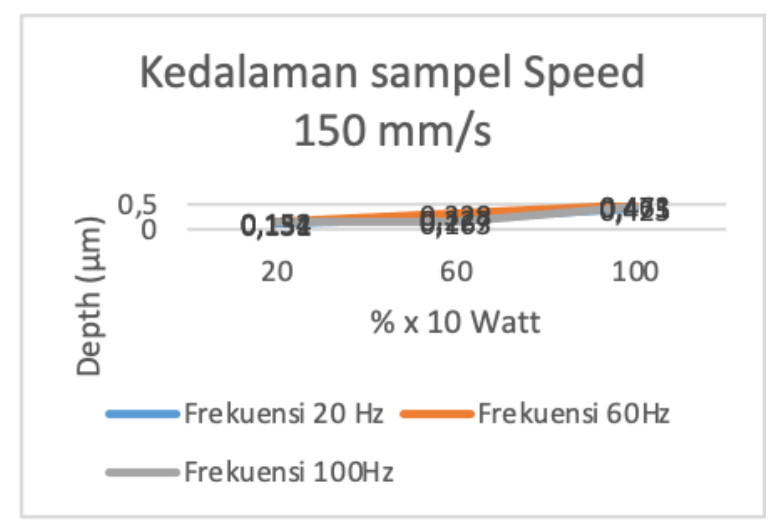

(c)

Gambar 3. Grafik kedalaman marking laser pada kecepatan (a) $50 \mathrm{~mm} / \mathrm{s}$, (b) $100 \mathrm{~mm} / \mathrm{s}$ dan (c) $150 \mathrm{~mm} / \mathrm{s}$

Dari gambar 3 diatas, terlihat bahwa kedalaman paling tinggi diperlihatkan pada frekuensi $60 \mathrm{~Hz}$ berapapun variabel kecepatan dari mesin. Pada dasarnya frekuensi yang tinggi akan mengakibatkan energi yang tinggi seperti yang dijelaskan dalam [8]

$$
\begin{gathered}
\lambda \mathrm{E}=\mathrm{hc}=1,99 \times 10^{-25} \text { joule-meter } \\
\text { dimana } \\
\lambda=\mathrm{c} / \mathrm{f}
\end{gathered}
$$

dimana

$$
\begin{array}{ll}
\lambda & =\text { panjang gelombang }(\mathrm{m}) \\
\mathrm{E} & =\text { Energi (Joule) } \\
\mathrm{h} & =\text { Tetapan planc sebesar } 6,63 \times 10-34 \text { Joule-second } \\
\mathrm{c} & =\text { kecepatan cahaya sebesar } 3 \times 108 \mathrm{~m} / \mathrm{s} \\
\mathrm{f} & =\text { frekuensi }(\mathrm{Hz})
\end{array}
$$

Dari tetapan diatas, dapat diketahui bahwa frekuensi yang besar $(100 \mathrm{~Hz})$, mempunyai panjang gelombang yang paling pendek, dan dengan demikian diharapkan mempunyai energi yang paling besar untuk membuat kedalaman marking yang paling besar. Namun sayangnya penembakan sinar laser dilakukan vertikal dengan sudut $0^{\circ}$. Dengan demikian, sebagian dari sinar laser akan kembali secara berlawanan arah $\left(180^{\circ}\right)$ dengan sinar tembakan, dan dengan demikian menjadi penghalangan bagi energi laser yang ditembakkan bagi lensa menuju material tersebut.

Fenomena ini akan mengakibatkan sebagian dari energi yang ditembakkan menjadi perisai bagi material, dan dengan demikian mengurangi kedalaman dari pemakanan material oleh laser tersebut. Semakin kecil energi yang ditembakkan oleh laser, maka akan semakin kecil energi yang menjadi perisai bagi material tersebut. Itulah sebabnya pada gambar 3 diperlihatkan bahwa kedalaman bagi frekuensi $20 \mathrm{~Hz}$ jauh lebih dalam ketimbang pada laser yang ditembakkan dengan frekuensi $100 \mathrm{~Hz}$. Walau demikian, semakin kecil daya energi yang ditembakkan oleh laser, tidak hanya mengurangi perisai yang terbentuk, namun juga mengurangi kekuatan memakan material. Dengan demikian, maka penembakan jenis ini tidak mempunyai tendensi yang linear, namun akan maksimum pada frekuensi atau parameter tertentu.

Dalam kasus ini, maka frekuensi $60 \mathrm{~Hz}$ menjadi titik maksimum, dimana energi pemakanan material berada pada kondisi yang tidak cukup besar - namun tidak terlalu kecil, dan energi yang menjadi perisai berada pada titik minimum terkecil. Dengan demikian pemakanan (proses marking) mempunyai kedalaman yang maksimum. 
Tabel 2. Hasil Mikrostruktur dengan pembesaran 430X untuk tiap parameter

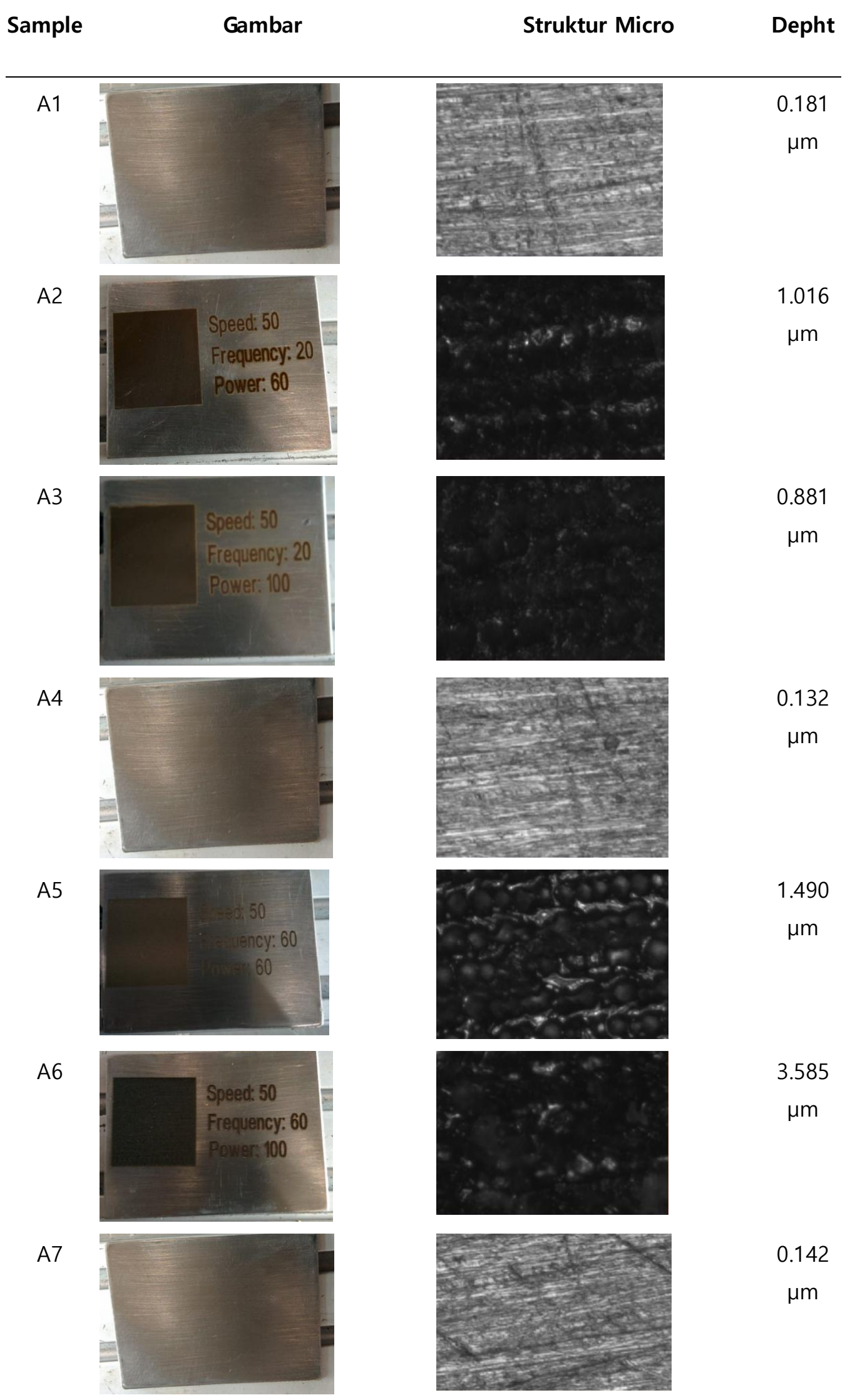


Jurnal METTEK Volume 6 No 2 (2020) pp 129 - 139

ojs.unud.ac.id/index.php/mettek

ISSN 2502-3829

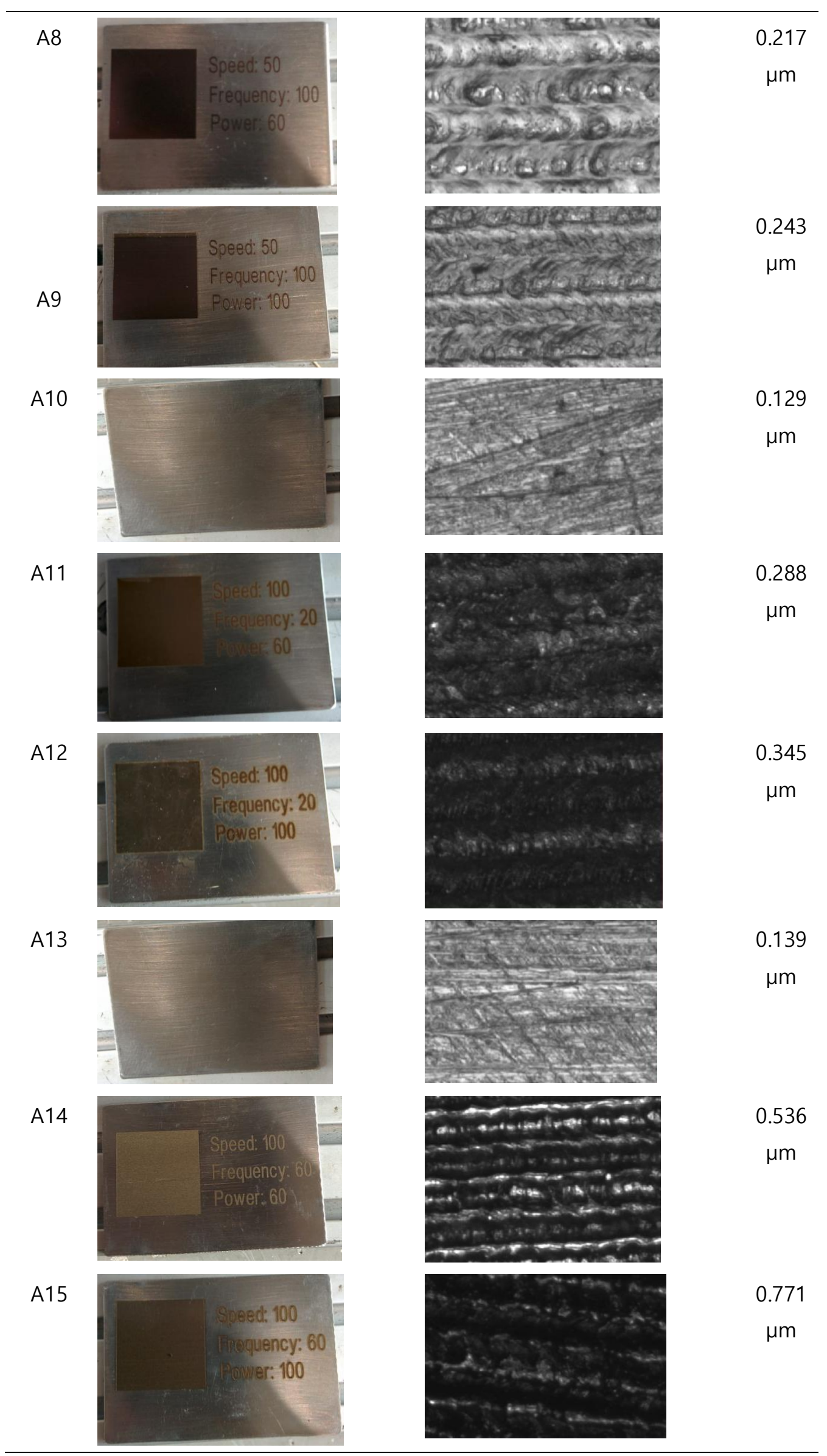




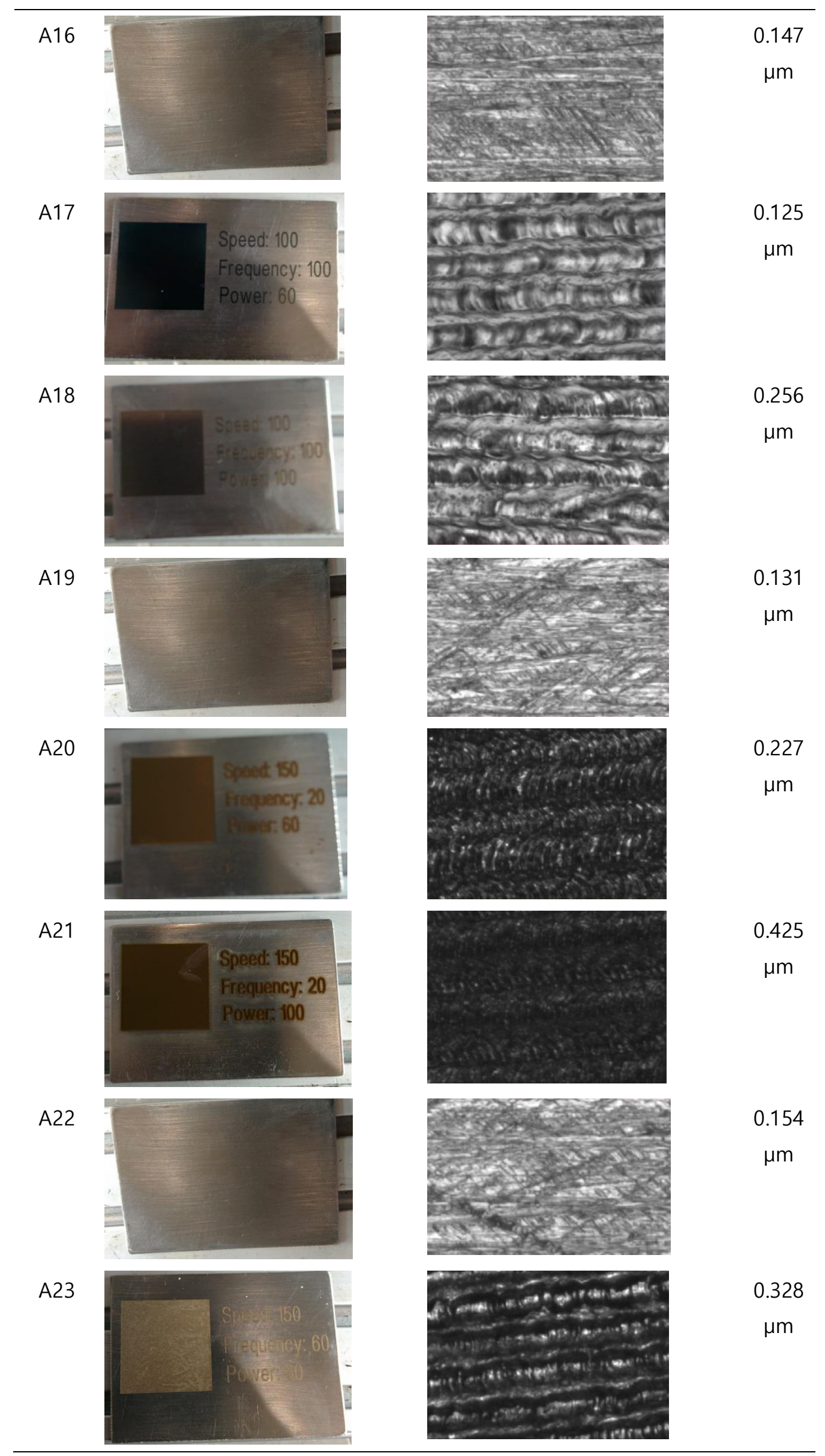

Dikky Antonius \& Cyrilus Pandu / METTEK Vol 6 No 2 (2020) 129 - 139 


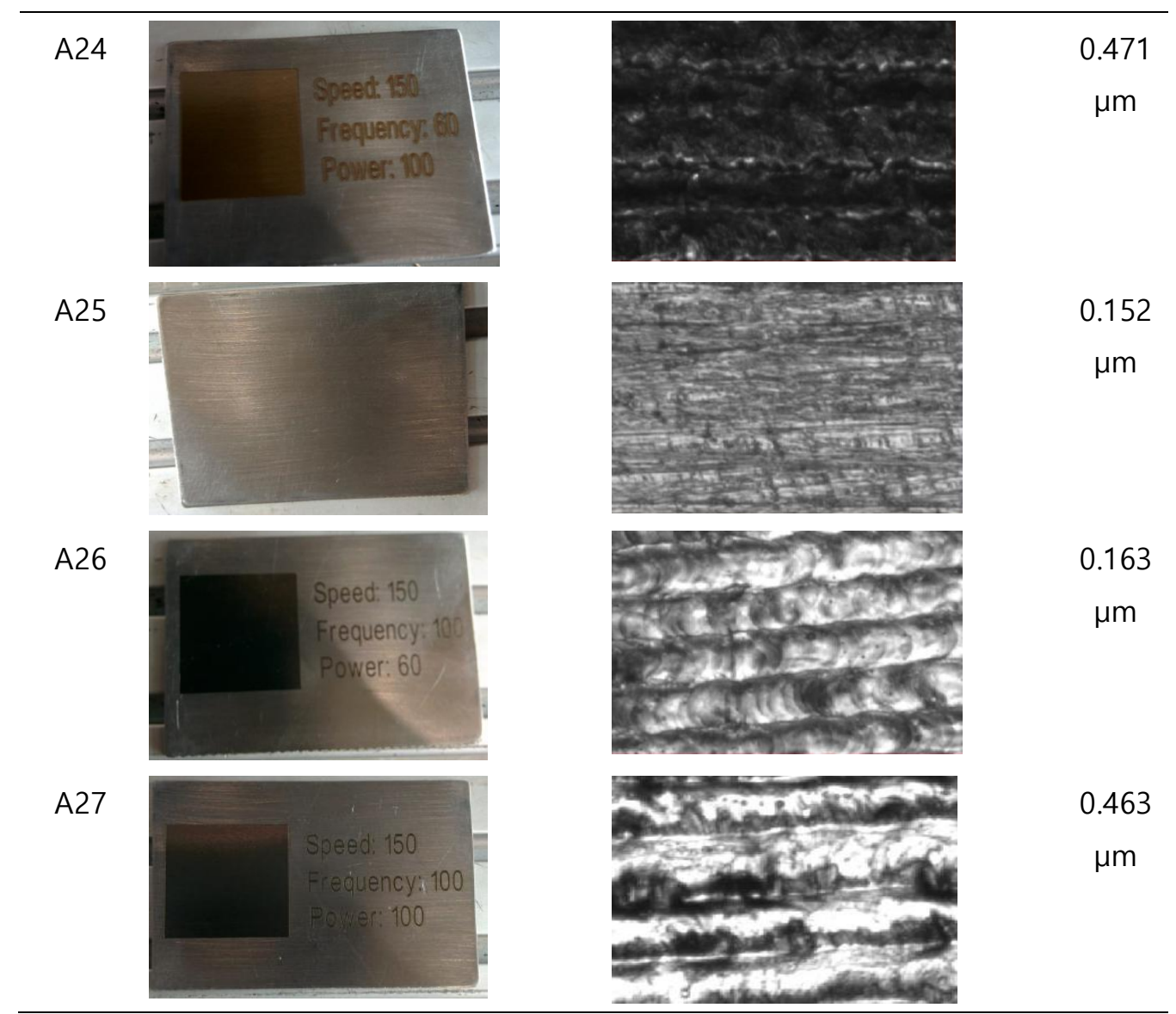

Tabel 2 Memperlihatkan kondisi permukaan marking baik secara visual maupun secara mikrostruktur dengan pembesaran hingga 430x bagi tiap-tiap parameter. Dari gambar diatas, terlihat jelas, bahwa penambahan persentase power dari mesin umumnya akan menaikan ukuran lebar dari marking laser tersebut. Ditambah lagi, setiap daya yang dinaikkan hingga $100 \%$ (10Watt) pada parameter frekuensi dan kecepatan yang berbeda sekalipun, maka lebar dari marking terlihat paling besar dibanding dengan daya lainnya (20\% dan $60 \%$ x 10 Watt). Lebar dari marking ini merupakan hasil dari divergence laser yang dapat diformulasikan dengan:

$$
r=D \text { Tan } \Theta[8]
$$

Dimana D merupakan jarak objektif antara lensa dengan benda kerja, dan $\Theta$ adalah sudut dari laser bergantung kepada jenis laser yang digunakan. Dikarenakan jenis laser yang digunakan sama, maka seharusnya lebar dari marking yang terbentuk harusnya adalah sama. Walaupun demikian, beberapa riset belakangan menunjukkan kaitan antara kaitan penumbukan energi dengan $\Theta$. 


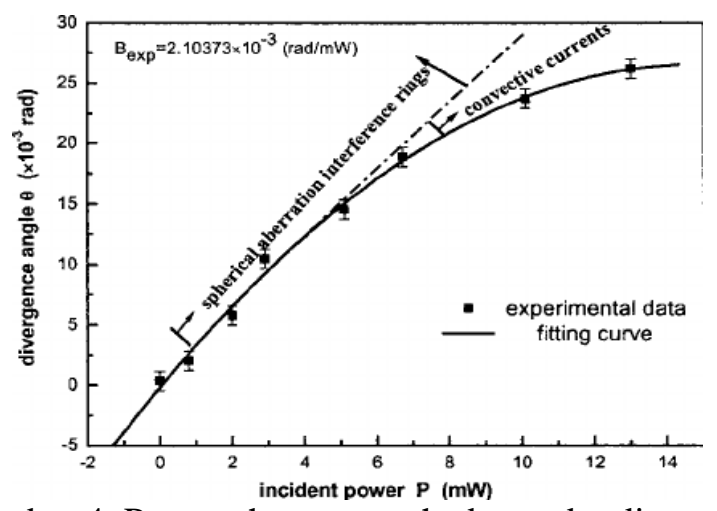

Gambar 4. Pengaruh power terhadap sudut divergence.[9]

Dari gambar terlihat bahwa $\Theta$ akan naik seiring kenaikan power yang diaplikasikan pada benda kerja, dan dengan demikian akan mempengaruhi lebar dari marking pada benda kerja. Di samping itu Tabel 2 memperlihatkan bahwa lebar paling besar terjadi/terbuat setiap frekuensi dan power dinaikkan pada kondisi maksimum - (100Hz dan $100 \%$ x10Watt $)$, terlepas berapa pun kecepatan dari mesin laser tersebut. Dalam mikrosturkturnya, terlihat juga bahwa permukaan material tersusun atas bagian-bagian yang seperti meleleh, yang menandakan kekuatan yang tinggi dari laser dan mengakibatkan stress pada material [10].

Sedang parameter kecepatan dari laser marking tidak terlalu berpengaruh kepada hasil kedalaman (depth) untuk frekuensi $20 \mathrm{~Hz}$ atau $60 \mathrm{~Hz}$. Walaupun demikian, hal itu berbeda untuk frekuensi $100 \mathrm{~Hz}$, kecepatan terlihat membuat kedalaman dari marking meningkat. Hal ini dikarenakan kecepatan mesin untuk bergeser cukup cepat untuk membuat pemantulan energi tidak terlalu besar sehingga menjadi perisai energi dan menghalangi penembakan dari laser. Dengan demikian, penembakan menjadi lebih efektif dan membuat kedalaman dari marking meningkat.

Di samping itu, peningkatan kecepatan mesin laser membuat kontras dari mikrostruktur meningkat. Dengan kata lain, peningkatan kecepatan dari mesin akan membuat permukaan makin kasar sehingga sinar yang dipantulkan akan lebih banyak yang tersebar (disperse) dan membuat penangkapan gambar menjadi lebih tajam. Namun sayangnya hal ini perlu dibuktikan lebih dalam dengan uji yang lebih valid.

\section{SIMPULAN} bahwa:

Berdasarkan hasil dari percobaan dan pembahasan diatas, maka dapat disimpulkan

1. Peningkatan frekuensi tidak semata-mata membuat kedalaman marking meningkat, walaupun peningkatan energi terlihat jelas. Hal ini dikarenakan penembakan secara vertical dengan sudut $0^{\circ}$ akan membuat pemantulan yang mengakibatkan sinar laser dihalangi.

2. Penambahan frekuensi dan power jelas membuat lebar dari motiv marking meningkat dikarenakan peningkatan divergence yang dipengaruhi energi yang diaplikasikan.

3. Parameter kecepatan membuat penembakan bagi frekuensi yang lebih besar mendapatkan kedalaman marking yang lebih tinggi dikarenakan kecepatannya cukup besar untuk membuat pemantulan dari energi berkurang

4. Parameter kecepatan dimungkinkan akan mengubah kekasaran dari permukaan benda kerja. Walau demikian, hal ini harus dapat di validasi lebih lanjut

\section{UCAPAN TERIMA KASIH}

Ucapan terima kasih diberikan kepada para dosen di fakultas teknik mesin UKI yang memberikan masukan, opini, dan ilmu pengetahuan. Kepada PT Kawan Lama yang 
memberikan tempat dalam hal pelaksanaan eksperimen untuk Laser marking. Kepada PT Mitutoyo yang memberikan tempat dalam hal pengujian, khususnya dalam hal kedalaman dan mikrostruktur. Kepada Universitas Udayana yang memfasilitasi publikasi dari paper ini.

\section{DAFTAR PUSTAKA}

[1] J. Qi, K. L. Wang, and Y. M. Zhu, "A study on the laser marking process of stainless steel," J. Mater. Process. Technol., vol. 139, no. 1-3, pp. 273-276, 2003.

[2] L. Sobotova and P. DEMEC, "Laser marking of metal materials," Carbon, vol. 26, no. 8, p. 59, 2015.

[3] D. K. Patel and D. M. Patel, "Parametric Optimization of Laser Engraving Process for different Material using Grey Relational Technique-A Review," Patel Al, vol. 3, no. 4, 2014.

[4] M. Kučera, M. Švantner, and E. Smazalová, "Influence of laser marking on stainless steel surface and corrosion resistance," in METAL 2014-23rd International Conference on Metallurgy and Materials, pp. 890-895,2014.

[5] E. F. Pieretti and M. D. M. das Neves, "Influence of laser marks on the electrochemical behaviour of the ASTM F139 stainless steel for biomedical application," Int. J. Electrochem. Sci., vol. 11, pp. 3532-3541, 2016.

[6] A. A. Cenna and P. Mathew, "Analysis and prediction of laser cutting parameters of fibre reinforced plastics (FRP) composite materials," Int. J. Mach. Tools Manuf., vol. 42, no. 1, pp. 105-113, 2002.

[7] A. Goeke and C. Emmelmann, "Influence of laser cutting parameters on CFRP part quality," Phys. Procedia, vol. 5, pp. 253-258, 2010.

[8] J. Hecht, Understanding Lasers: An Entry-Level Guide. John Wiley \& Sons, 2011.

[9] "FIG. 4. Divergence angle vs incident power.," ResearchGate. https://www.researchgate.net/figure/Divergence-angle-vs-incidentpower_fig4_224491896 (accessed Jul. 18, 2020).

[10] D. A. Hutauruk, "STUDI PENGARUH LAKUPANAS ANILING TERHADAP RESIDUAL STRESS PADA BAJA TAHAN KARAT 304L," J. Kaji. Ilm. UBJ, vol. 15, no. 1, pp. 20-31, 2015. 